NBSIR 84-2917

\title{
Environmental Cycling of Cellulosic Thermal Insulation and Its. Influence on Fire Performance
}

J. Randall Lawson

U.S. DEPARTMENT OF COMMERCE

National Bureau of Standards

National Engineering Laboratory

Center for Fire Research

Gaithersburg, MD 20899

August 1984

Supported in part by:

Department of Energy

- $A C \longrightarrow$ Washington, DC 


\section{ENVIRONMENTAL CYCLING OF CELLULOSIC THERMAL INSULATION AND ITS INFLUENCE ON FIRE PERFORMANCE}

J. Randall Lawson

U.S. DEPARTMENT OF COMMERCE

National Bureau of Standards

National Engineering Laboratory

Center for Fire Research

Gaithersburg, MD 20899

August 1984

Supported in part by:

Department of Energy

Washington, DC

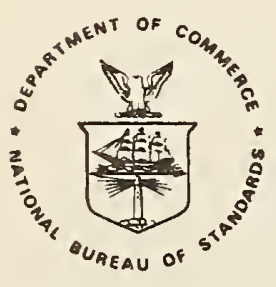

U.S. DEPARTMENT OF COMMERCE, Malcolm Baldrige, Secretary NATIONAL BUREAU OF STANDARDS, Ernest Ambler, Director 

Page

List of Tables $\ldots \ldots \ldots \ldots \ldots \ldots \ldots \ldots \ldots \ldots \ldots \ldots \ldots \ldots \ldots \ldots \ldots \ldots \ldots \ldots$ iv

List of Figures $\ldots \ldots \ldots \ldots \ldots \ldots \ldots \ldots \ldots \ldots \ldots \ldots \ldots \ldots \ldots \ldots \ldots \ldots \ldots$ v

Abstract $\quad \ldots \ldots \ldots \ldots \ldots \ldots \ldots \ldots \ldots \ldots \ldots \ldots \ldots \ldots \ldots \ldots \ldots \ldots \ldots \ldots \ldots \ldots \ldots \ldots$

1. INTRODUCTION $\ldots \ldots \ldots \ldots \ldots \ldots \ldots \ldots \ldots \ldots \ldots \ldots \ldots \ldots \ldots \ldots \ldots \ldots \ldots \ldots \ldots \ldots . . \ldots \ldots$

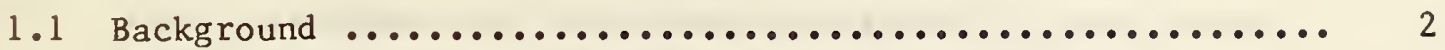

1.2 Fire-Retardant Chemicals and Cellulosic Materials ....... 5

2. CLIMATE SURVEY $\ldots \ldots \ldots \ldots \ldots \ldots \ldots \ldots \ldots \ldots \ldots \ldots \ldots \ldots \ldots \ldots \ldots \ldots$

3. ENVIRONMENTAL CYCLES $\ldots \ldots \ldots \ldots \ldots \ldots \ldots \ldots \ldots \ldots \ldots \ldots \ldots \ldots \ldots \ldots \ldots$

4. THERMAL INSULATION SPECIMENS $\ldots \ldots \ldots \ldots \ldots \ldots \ldots \ldots \ldots \ldots \ldots \ldots \ldots \ldots \ldots$

5. FIRE TEST PROCEDURES .............................. 10

6. InSULATION DENSITY MEASUREMENTS........................ 12

6.1 Initial Density Determinations.................... 12

6.2 Smolder "Break-Point" Density Determination............. 12

7. ENVIRONMENTAL CYCLING TEST RESULTS.................... 13

7.1 Smoldering Combustion Test Results ................. 13

7.2 Critical Radiant Flux Test Results ................. 15

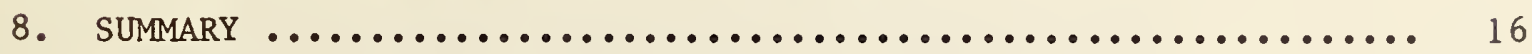

9. CONCLUSIONS ................................... 17

10. ACKNOWLEDGEMENTS ................................. 19

11. REFERENCES ...................................... 19 


\section{LIST OF TABLES}

Page

Table 1. Conditioning Cycle Specified in ASTM C739-77 .......... 33

Table 2. Evaluation of ASTM C739-77 Conditioning Method ......... 34

Table 3. Cities Used in the Analysis of Climatic Conditions ...... 35

Table 4. Environmental Cycles Used to Condition Specimens ....... 36

Table 5. Composition of Cellulosic Insulation Materials ......... 37

Table 6. Blown and Settled Densities for Cellulosic Thermal

Insulation Samples .......................... 38

Table 7. Smoldering Combustion Test Results .................. 39

Table 8. Critical Radiant Flux Test Results ................ 40 
Figure 1. Relative humidity vs. dry bulb temperature for Albuquerque, New Mexico, 1977-1978 .................

Figure 2. Relative humidity vs. dry bulb temperature for

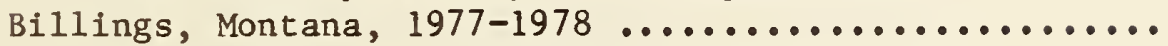

Figure 3. Relative humidity vs, dry bulb temperature for Boise, Idaho, 1977-1978

Figure 4. Relative humidity vs. dry bulb temperature for

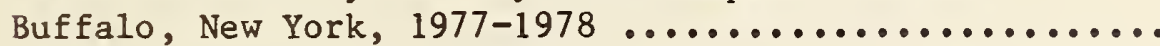

Figure 5. Relative humidity vs. dry bulb temperature for Chicago, Illinois, 1977-1978

Figure 6. Relative humidity vs. dry bulb temperature for Duluth, Minnesota, 1977-1978

Figure 7. Relative humidity vs. dry bulb temperature for New Orleans, Louisiana, 1977-1978 ................

Figure 8. Relative humidity vs. dry bulb temperature for Portland, Oregon, 1977-1978

Figure 9. Relative humidity vs. dry bulb temperature for Richmond, Virginia, 1977-1978 ..................

Figure 10. Relative humidity vs. dry bulb temperature for San Francisco, California, 1977-1978 ............. 30

Figure 11. Relative humidity vs. dry bulb temperature for

Figure 12. Composite extreme climate data for eleven cities in the 

ENVIRONMENTAL CYCLING OF CELLULOSIC THERMAL INSULATION

AND ITS INFLUENCE ON FIRE PERFORMANCE

J. Randa11 Lawson

Abstract

A study was conducted on climatological data for eleven cities located throughout the United States. Findings from this environmental study were used to develop conditioning cycles for a research project on the influence of environments on the fire performance of loose-fill cellulosic thermal insulation. Six cellulosic insulation materials with different compositions of fire retardant chemicals at an add-on level of 25 percent by weight were specially manufactured for this study. These materials were tested for fire performance using the smoldering combustion test and the attic flooring radiant panel test to establish a baseline.

After the materials were exposed to the various environmental cycles, they were tested for fire performance. Results from these tests show that environmental exposure can have a significant effect on the fire performance of cellulosic insulation materials and indicates that long term fire protection provided by fire retardant compounds may be limited. 
Key Words: climate; cellulose; environments; fire performance; thermal insulation; fire retardants.

\section{INTRODUCTION}

\subsection{Background}

Loose fill cellulosic thermal insulation has been used in housing for many years in an attempt to reduce heating and cooling costs. With the rapid rise in energy costs over the last decade, many home owners and owners of commercial buildings have attempted to increase resistance to thermal losses by installing insulation or adding additional insulation to the structure. In 1977 , a number of fire problems were identified with some cellulosic insulation products $[1]^{*}$. As a result, many questions were raised concerning the fire properties of cellulosic insulation, job site installation practices for the materials, standards for manufacturing, and standards for purchasing the products. In addition to these questions, two other questions arose. One question related to the permanence of fire retardant chemicals. The second addressed the effect of various environmental conditions on fire performance.

The material standards generally used for specifying cellulosic thermal insulation for buildings in 1977 were the American Society for Testing and Materials (ASTM) Standard C 739 [2] and Federal Specification HH-I-515C [3]. The federal specification was based on the requirements stated in ASTM C 739. This ASTM standard recognized the fact that cellulosic thermal insulation

* Numbers in brackets indicate literature references at the end of this report. 
materials should be conditioned in some fashion before being submitted to fire performance tests, but the conditioning procedure, as shown in the next paragraph, did not appropriately address the fire problems associated with the insulation. The ASTM C 739 conditioning procedure is presented in table 1. When viewing table $\mathrm{l}$, it should be noted that $\mathrm{C} 739$ called for fire testing the insulation immediately following the last 24 hour conditioning cycle. The fact that fire testing of the materials occurred only 24 hours after being exposed to a high relative humidity environment caused questions to be raised concerning the conditioning methods validity•

An evaluation of this conditioning procedure was carried out at NBS during 1978. The study was carried out using three commercially manufactured cellulosic insulation materials. The fire retardant chemical compositions for these materials were not supplied by the manufacturers, and no chemical analyses were done to determine the constituents or amount of add-on. Two different sets of specimens were taken from each of the three materials. One set of specimens was conditioned using the C 739 method, and the second set of control specimens was conditioned for two days in a $23 \pm 3^{\circ} \mathrm{C}\left(73 \pm 5^{\circ} \mathrm{F}\right)$ and $50 \pm 5$ percent relative humidity conditioning environment. For a period of about one month before the samples were conditioned, the materials were stored, in their product bags, in an environmentally controlled laboratory which had an environment similar to the $23^{\circ} \mathrm{C}$ and 50 percent relative humidity condition mentioned above.

When the specimens were conditioned using the C 739 method, they were wet upon completing the fourth cycle. This wet condition was not the result of any error in carrying out the C 739 conditioning procedure but was the natural 
end product of the conditioning method. Since the materials were wet, they were not fire tested immediately, but were placed in the $23^{\circ} \mathrm{C}$ and 50 percent relative humidity conditioning room for seven days before they were tested.

The fire tests conducted on the insulation materials measured surface flammability and determined the propensity for smoldering. Test methods being proposed by the General Services Administration (GSA) to replace the existing ASTM E 84 fire test for surface burning characteristics of bullding materials were used. The proposed test methods were the critical radiant flux test and the smoldering combustion test [4]. These test procedures are outlined in section 5 of this report. Test results using these procedures are shown in table 2. The test results show that material "A" improved significantly with the smoldering combustion test after the C 739 environmental exposure, and material "B" showed a major improvement in critical radiant flux results. Material " $C$ " did not show a significant change for either fire test. In general, variability in test results for all three specimens increased with the C 739 environmental cycle when compared to the control specimen test results. These findings as well as others associated with the ASTM E 84 fire test procedure resulted in the GSA, which maintains standards for government purchases, dropping the requirements for ASTM C 739 which included the conditioning method and the E 84 fire test and adopting a new standard.

The conditioning procedure in the new GSA standard HH-I-515D [4] required that cellulosic insulation materials be conditioned to equilibrium or for a minimum of 48 hours, whichever is greater, at $21 \pm 3^{\circ} \mathrm{C}\left(69.8 \pm 5.4^{\circ} \mathrm{F}\right)$ and a relative humidity of $50 \pm 5$ percent immediately prior to fire testing. This conditioning procedure did not take into account any aspect of specimen aging but attempted only to normalize the materials before testing. 
In 1979, the Consumer Product Safety Commission published a standard for cellulosic thermal insulation that was designed to reduce or eliminate an unreasonable risk of injury to consumers from flammable or corrosive cellulose insulation [5]. At that time, the consumer required immediate action in establishing a new standard because some unsafe products were being marketed. The standard was published with no requirement for a fire retardant permanency determination.

The purpose of this report is to provide information on environmental conditions to which insulation materials are exposed that may influence fire retardant permanency, and to show the sensitivity of the fire performance of cellulosic thermal insulation materials to selected environmental exposure conditions that are found in varlous parts of the continental United States.

\subsection{Fire-Retardant Chemicals and Cellulosic Materials}

Cellulosic thermal insulation materials are typically manufactured from ground waste paper, wood pulp, or waste cotton. These materials are recognized to be easily ignited and to have a potential for fire growth. In order to take advantage of the good insulating properties of these cellulosic materials, manufacturers developed product formulations using known fireretardant chemicals. A study conducted at the Oak Ridge National Laboratory [6] on 51 commercially produced loose-fill cellulosic insulations showed that manufacturers used chemical fire-retardants with add-on levels that ranged froin 14 to 36 percent by weight. 
Some of the most common additives used as fire-retardants are borax, boric acid, aluminum sulfate, ammonium sulfate, and ammonium phosphate. Borax has been identified as the primary fire-retardant additive used to improve flaming resistance [7]. The most common additive used to improve resistance to smoldering combustion is boric acid, but compounds containing sulfur and phosphorous are also used. Some chemical compounds, e.g., halides, phosphates, and sulfates, are credited with inhibiting both flaming and smoldering combustion in small scale tests with cellulosic fabrics [8].

The processes resulting in flaming or smoldering inhibition are not clearly understood, but it has been suggested that the fire-retardant chemicals serve as "chain-breakers" or "free radical scavengers" in the oxidation reactions [9]. This lack of understanding concerning the fire behavior of the fire-retardant chemicals is compounded by the lack of knowledge concerning the effects of environment on the chemicals. It is known that some fire-retardant chemicals are water-soluble, e.g. boric acid and sodium borate, and it is not uncommon for moisture to develop in wall cavities or in some attic constructions as a result of variations in weather conditions or use of the structure. Where moisture develops, these soluble fire-retardant chemicals may be washed away from the insulation. A second area of interest is associated with the fact that many of the cellulosic insulation materials manufactured are produced by mixing dry granular or powdered chemicals with the cellulose fibers. It has been noted that these dry chemicals have a tendency to settle-out, as a result of vibrations and gravity, and collect at the bottom of the structure containing the insulation. This leaves an insulation which is highly variable in its fire-resistance performance [10]. This physical separation is not studied in this project. A third problem in ques- 
tion is that boron containing compounds have an appreciable low vapor pressure, and they have been found to sublimate as temperatures rise [6]. The evaporation of the fire-retardant chemical also results in the possibility of variable fire performance characteristics.

When the environmental variability of the chemical and physical properties of fire-retardant additives are coupled with the fire properties of loose fiber cellulosic materials, it is clear that fire-retardant permanence is an important issue. As described above, environmental history may have a significant influence on the behavior of cellulosic insulation materials if they become exposed to an ignition source or a fire environment. In an attempt to better define a range of environmental conditions that thermal insulation may be exposed to, a climate survey was conducted.

\section{CLIMATE SURVEY}

A survey of weather conditions for eleven cities located in the continental United States was conducted to obtain information on the various environments to which thermal insulation is exposed. The cities are listed in table 3. These eleven cities were selected because their range of weather conditions are representative of those found in the United States. Dry bulb temperatures and relative humidities for these cities were analyzed using climatological data for years 1977 and 1978. The data were obtained from the National Oceanic and Atmospheric Administration (NOAA), and the Koppen Classification System for climatic types, as modified by Trewartha [11,12], was used for analysis. For each of the eleven cities, average monthly dry bulb temperature versus average monthly relative humidity was plotted, 
providing a range of temperature and humidity conditions for each city. These plots can be seen in figures 1 through 11 . These data were then combined into one group, and the polygon in figure 12 shows the extreme conditions. The aging cycles used in this study were developed by selecting significant high temperature and extreme relative humidity conditions from the polygon.

\section{ENVIRONMENTAL CYCLES}

Three conditioning methods were used in this study to evaluate the effects of environmental exposures on the fire performance of fire-retardant treated cellulosic insulation materials. These three methods are presented in table 4. The first environmental conditioning method was used to develop baseline data on the insulation materials. The materials had been stored in a well controlled air-conditioned laboratory for several months before they were submitted to the baseline environmental exposure. The laboratory environment over the storage period was almost identical to that used in the conditioning chamber on the baseline exposure. All of the critical radiant flux test specimens were blown into their metal specimen trays before they were conditioned, and all smoldering combustion test specimens were blown before being hand loaded into their test containers prior to being conditioned.

Environmental cycles $A$ and $B$ shown in table 4 were designed to expose the insulation materials to more extreme conditions than that used in the baseline tests. However, the conditioning cycles had to be kept fairly short in order to provide a procedure that may be used by industry for evaluating their

products. It was recognized that in a high production rate industry, like the cellulosic insulation industry, lengthy conditioning cycles and testing 
perlods create significant warehousing and marketing problems. These considerations resulted in the selection of the eight day environmental cycles. These cycles were chosen with the knowledge that a longer conditioning procedure may be necessary to obtain a more reliable indication of the effects of environment on fire performance.

Because fire-retardant chemicals are likely to change or migrate at higher temperatures, two elevated temperature climatic conditions were selected for cycles A and B. The major differences between these two experimental environmental cycles are reflected in the percent relative humidity. The conditions used in the first four days of cycle $A$ are shown as extreme environmental conditions in the climate polygon, figure 12. This temperature and humidity condition is similar to that found in Tucson, Arizona during the summer. See figure 11. The temperature for cycle A was increased from $37^{\circ} \mathrm{C}$ to $60^{\circ} \mathrm{C}$ in order to reproduce attic temperatures recorded in the western part of the United States. The temperature for this cycle was also increased to remove free moisture from the insulation materials, and it was an attempt to accelerate the aging process by thermally stressing the materials. The second part of cycle A was used to normalize the insulation specimens for testing. It is understood that more time may be needed for a specimen to completely normalize after being exposed to an extreme environment. However, the four day cycle at $23^{\circ} \mathrm{C}$ and 50 percent relative humidity was used to economize on time and meet the requirement for a short cycling procedure as mentioned in the paragraph above.

The first environmental condition shown in cycle $B$ is also representative of an extreme climatic condition identified in the climate survey. See the 
climate polygon in figure 12. This climatic condition exhibits a high relative humidity environment with a moderately high temperature. Figure 9 shows that these conditions are similar to that experienced in Richmond, Virginia. Again, the ambient temperature found in the climate survey was increased to represent a higher temperature that may occur in an attic, and it was also increased so that the insulation materials would be stressed. The high relative humidity environment was selected because it would provide a moist condition which could result in the migration of soluble fire-retardant chemicals. After the initial four days of exposure at the extreme conditions with cycle $B$, the specimens were then exposed to the same normalizing moderate environment as used in cycle A.

\section{THERMAL INSULATION SPECIMENS}

The six cellulosic thermal insulation materials used in this study are listed in table 5. Each specimen was prepared by a manufacturer that possessed the equipment and working knowledge of the cellulosic insulation manufacturing process. The specimens include fire retardant chemical compositions that have been identified in commercial insulation products.

\section{FIRE TEST PROCEDURES}

Two test methods were used to evaluate the thermal insulation materials fire properties after they were exposed to the environmental conditions described in section 3. One procedure, the Attic Flooring Radiant Panel test [13], was used to measure changes in critical radiant flux. The second test method, the Smoldering Combustion test [13], measured changes in smoldering propensity 
The radiant panel test apparatus exposes a $100 \mathrm{~cm}$ long specimen tray filled with thermal insulation at its blown density to a radiant energy source. The gas fired radiant panel produces a heat flux profile along the length of the specimen which ranges from $1.1 \mathrm{~W} / \mathrm{cm}^{2}$ at the specimen end nearest the radiant panel to $0.1 \mathrm{~W} / \mathrm{cm}^{2}$ heat $\mathrm{flux}$ at the other end of the specimen. The specimen is ignited by a small pilot flame at the end closest to the radiant pane1. If the specimen burns, flames move along the specimen away from the radiant panel and then may stop at some point which is associated with the chemical and thermophysical properties of the material. The flame will selfextinguish when thermal feed-back from the burning specimen and irradiance from the radiant panel are insufficient to sustain flaming combustion. The distance burned to flame extinguishment is converted to a measure of radiant energy using a flux profile generated during test calibration, and the results are reported as "critical radiant flux". A cellulosic thermal insulation material must have a critical radiant $f l u x \geqslant 0.12 \mathrm{~W} / \mathrm{cm}^{2}$ to pass the test.

The smoldering combustion test exposes a thermal insulation specimen at its settled density, in an open-top $20 \mathrm{~cm}$ square stainless steel box which is $10 \mathrm{~cm}$ deep, to a smoldering non-filter tip cigarette. The lit cigarette is inserted with the smoldering end up into an $8 \mathrm{~mm}$ diameter vertical hole which is located in the center of the specimen. The cigarette and specimen are allowed to burn until smoldering is no longer evident. After the specimen holder has cooled, the specimen is reweighed. The material will pass the test if the mass loss resulting from burning is $\leq 15$ percent of the initial specimen mass. Test results are reported on the basis of percent mass loss. 


\section{INSULATION DENSITY MEASUREMENTS}

\subsection{Initial Density Determinations}

Since the smoldering combustion test can be influenced by specimen density, the insulation sample densities were measured using the procedure described in reference 13. Two different densities for each sample are shown in table 6. The blown density represents the insulation density just after it was blown through the cyclone apparatus specified in reference 13. This density is similar to that expected from material blown into a building attic space using a commercial insulation blower. The settled density reported in Table 6 is the result after each material was shaken for a five minute period on a $1.19 \mathrm{~cm}$ vertical displacement shaker. The settled density measurement is designed to provide an estimate of a possible change in density that may occur over a long period of time after a material has been blown into a structure.

\subsection{Smolder "Break-Point" Density Determination}

After the settled densities were determined, each insulation sample was tested to determine if it would smolder at its settled density. The smoldering combustion test discussed in section 5 was used in the evaluation. Each test in this phase of the study was carried out after the specimens were conditioned using the baseline environmental exposure shown in table 4 . All of the insulation materials passed the tests by exhibiting little or no smolder propagation. Since all materials passed the test, no data are shown in the test result tables. 
Upon completing the initial smoldering combustion tests, a series of experiments was conducted to determine the "break-point density" where each of the different insulation materials would begin to smolder. This was done to find a density that could be used to evaluate the effect of environmental cycling on the smoldering propensity of each material. To accomplish this, insulation specimen densities were gradually increased from their settled densities, test by test, until smoldering combustion occurred. Compare settled densities in table 6 with the selected test densities for the test program in table 7. The densities for all of the samples except materials 3 and 4 were increased. It was found that only a very slight increase in density would cause materials 3 and 4 to smolder. Therefore, the test densities for these materials were maintained at their settled density. Material 1 exhibited an unusual characteristic that is not shown in the test result tables. This material showed smoldering tendency at a density of $88.0 \mathrm{~kg} / \mathrm{m}^{3}$, but it showed no indication of smoldering at a higher density of $96.0 \mathrm{~kg} / \mathrm{m}^{3}$. This indicates that an upper density limit exists and that the density range which supports smoldering combustion using this test method is fairly narrow for this material. When the "break-point" densities were selected, the materials were then ready for use in evaluating the effects of environmental cycling.

7. ENVIRONMENTAL CYCLING TEST RESULTS

\subsection{Smoldering Combustion Test Results}

Smoldering combustion test results for each of the three environmental exposures are presented in table 7. It should be noted that the values for 
mass prior to smoldering in exposure cycles $A$ and $B$ represent the specimen's mass after environmental cycling, and they reflect a relative gain or loss in moisture when compared to the values of mass after the baseline environmental exposure.

Three tests were conducted on samples of each of the six insulation products after they were exposed to the various environmental cycles. Additional tests using each of the specially manufactured insulation materials were not possible since the supply was being depleted. However, the data obtained from these limited test results do suggest basic trends that can be seen in tables 7 and 8 .

Two of the six materials, 2 and 5, do reflect significant changes in smoldering behavior with changes in environmental exposure. All of the test specimens for material 2 passed with exposure $A$, and all of the test specimens failed with exposure B even though there was a marked increase in specimen mass due to moisture gained during environmental cycling. Material 5 exhibited two failures after being exposed to environment $A$ and had no failures when exposed to environmental cycle B. Both of the above materials contained similar fire retardant chemical additives, but they reacted differently after experiencing the two different environmental cycles.

Environmental exposures $A$ and $B$ had little or no effect on the smoldering behavior of materials 1,3 , and 4. The apparent change in smoldering seen for material 6 should not be given too much emphasis since the values obtained for the baseline condition were developed at a higher density of $88.0 \mathrm{~kg} / \mathrm{m}^{3}$. The density for material 6 was lowered to $84.0 \mathrm{~kg} / \mathrm{m}^{3}$ for the remaining environ- 
mental exposures in an attempt to obtain better sensitivity at the smoldering "break-point". Even with this change in density, the difference in smoldering combustion characteristics for material 6 with exposures A and B do not appear to be conclusive.

\subsection{Critical Radiant Flux Test Results}

Critical radiant flux tests using the attic flooring radiant panel test apparatus were conducted on each of the six thermal insulation materials at their blown densities. Data for materials before and after exposure to the environmental conditions can be seen in table 8. Baseline data for the materials showed that flame retardant performance on several of the sample materials was not adequate. Material 4 and 5 had failures, values $<0.12$ $\mathrm{W} / \mathrm{cm}^{2}$, on each test conducted for critical radiant flux. Also, it should be noted that material 4 exhibited failures on all tests regardless of the environmental conditions. This insulation material contained borax and ammonium sulfate, which are both considered to be flame retardants, but these test results indicate unacceptable performance. In addition to the failures experienced with materials 4 and 5, material 2 had two failures and materials 1 and 3 had one clear failure each, with marginal results on the other two tests.

After the six materials were exposed to conditioning environment A, material 1 showed an increase in flame spread with three failures as compared to results from tests after the baseline environmental exposure. Material 6 exhibited one failure out of three tests after exposure A. This indicates some loss in flame resistance. Material 2 had a slight improvement in test 
results after exposure $A$ and material 3 showed no change. Materials 4 and 5 failed all three critical radiant flux tests after the exposure to environment A conditions.

When the materials were exposed to environmental cycle $B$, all specimens except material 4 showed improvement in critical radiant flux values. Material 6, which exhibited one fallure, showed a significant improvement in test results with the second and third tests in this set as compared to results from the baseline environmental exposure and environmental exposure A.

\section{SUMMARY}

This report provides information on various environmental conditions experlenced in eleven different geographical locations in the continental United States. Data on these climates provided basic information for the selection of environmental conditions used in this study, and they provide a collection of climatic data which may be used in further research on the environmental cycling of thermal insulation materials.

Six cellulosic thermal insulation materials containing chemical fire retardants were exposed to different environmental conditions and were tested for changes in fire performance. Each insulation material was tested for fire performance using the smoldering combustion and the critical radiant flux test procedures [13]. Two of the materials showed improvements after being exposed to a high temperature/high humidity environmental cycle and had poor results after being exposed to a high temperature/low humidity environment when tested with the smoldering combustion test procedure. Another material experienced 
poor results from the high temperature/high humidity environmental cycle and inproved with the high temperature/low humidity environmental cycle.

When the materials were tested for critical radiant flux, all except one had failures with the basic environmental conditioning of four days at $23^{\circ} \mathrm{C}$ and $50 \%$ relative humidity. This occurrence did not provide a good base for observing differences in test results after the materials were exposed to the two environmental cycles. However, a trend was suggested by the test results; generally, critical radiant flux test results indicated that fire performance of the materials became worse after they were exposed to a high temperature/ low humidity environment and it was improved by a high temperature/high humidity environment. The improvement noted may be attributed to increased moisture in the cellulosic insulation. This observation does not hold true when comparing the smoldering combustion test results with the critical radiant flux test results. Material 2 showed a reverse in this trend.

\section{CONCLUSIONS}

Test results from this research project are mixed, but provide insight into the complex behavior of fire retardant chemicals on the fire performance of cellulosic thermal insulation materials when they are exposed to various environmental conditions. In spite of the mixed results, certain conclusions can be made.

1. Test results show that environmental cycling can affect the fire performance of cellulosic thermal insulation materials. 
2. Cycling through either high temperature/high humidity or high temperature/low humidity environments can adversely influence the protection provided by chemical fire retardants in cellulosic thermal insulation.

3. These results indicate that fire performance behavior and the effects of environmental exposure are markedly affected by the composition and content of the chemical fire retardants used.

4. Because of the mixed results from tests in this project and the limited number of tests conducted, a simple conditioning cycle cannot be recommended. In order to properly design an acceptable environmental cycling procedure for the permanency of fire retardant chemicals and their effect on fire performance, a more comprehensive research project is required. 


\section{ACKNOWLEDGEMENTS}

Appreciation is extended to Mr. David Klein for his assistance in planning the project, developing the environmental data, and obtaining the insulation materials. Mr. Newton Breese extracted the environmental data presented in this report from computer tapes provided by the National Oceanic and Atmospheric Administration. Special recognition is given to Mr. Eric Mittlefehldt who spent many hours preparing test specimens, maintaining close control over the environinental conditioning cycles, and conducting fire tests on all of the materials discussed in this report. Appreciation is also extended to Mr. Fred Gallagher (Mineral Research and Development Company) and Mr. Robert Anderson for their assistance in obtaining the thermal insulation materials. The Consumer Product Safety Commission Engineering Laboratory is also recognized for their assistance in developing blown and settled density test data on the six thermal insulation materials.

\section{REFERENCES}

[1] Gross, D., A Preliminary Study of the Fire Safety of Thermal Insulation for Use in Attics or Enclosed Spaces in Residential Housing, National Bureau of Standards (U.S.), NBSIR 78-1497 (1978).

[2] Standard Specification for Cellulosic Fiber (Wood-Base) Loose-Fill Thermal Insulation, ASTM C739-77, American Society for Testing and Materials, Philadelphia, PA (1977).

[3] Insulation Thermal (Loose Fill for Pneumatic or Poured Application): Cellulosic or Wood Fiber, Federal Specification HH-I-515C (April 13, 1976).

[4] Insulation Thermal (Loose Fill for Pneumatic or Poured Application): Cellulose or Wood Fiber, Federal Specification HH-I-515D (June 15, 1978).

[5] Interim Safety Standard for Cellulose Insulation, Consumer Product Safety Commission, Federal Register, Vo1. 44, No. 47, March 8, 1979. 
[6] Yarbrough, D.W., McElroy, D.L. and Harris, W.W., Properties and Testing of Loose-Fill Cellulosic Insulation, ORNL/TM-6433, Oak Ridge National Laboratory, Oak Ridge, TN (February 1982).

[7] Ohlemiller, T.J. and Rogers, F.E., Cellulosic Insulation Material II. Effect of Additives on Some Smolder Characteristics, Combustion Science and Technology, Vol. 24, pp. 139-152, 1980.

[8] McCarter, R.J., Combustion Inhibition of Cellulose By Powders: Preliminary Data and Hypotheses, Fire and Materials, Vol. 5, No. 2, 66-72, (June 1981).

[9] McCarter, R.J., "Smoldering Combustion of Cotton and Rayon, Proceedings, Symposium on Textile Flammability, New Orleans, LA (April 20-21, 1977).

[10] Lawson, J.R., Interlaboratory Evaluation of the Attic Floor Radiant Panel Test and Smoldering Combustion Test for Cellulose Thermal Insulation, National Bureau of Standards (U.S.), NBSIR 79-1588 (1979).

[11] Trewartha, G.F., An Introduction to Weather and C1imate, 2nd Edition, McGraw-Hill, 1943.

[12] Wesse1, C.J., Thom, H.C.S., "C1imate and Deterioration", in Greathouse, G.A. and Wessel, C.J., editors, Deterioration of Materials, Reinhold, 1954.

[13] Test Manual, Cellulosic Insulation, Part 1 - Radiant Panel and Smoldering Combustion Test, U.S. Consumer Product Safety Commission, Washington, DC. 


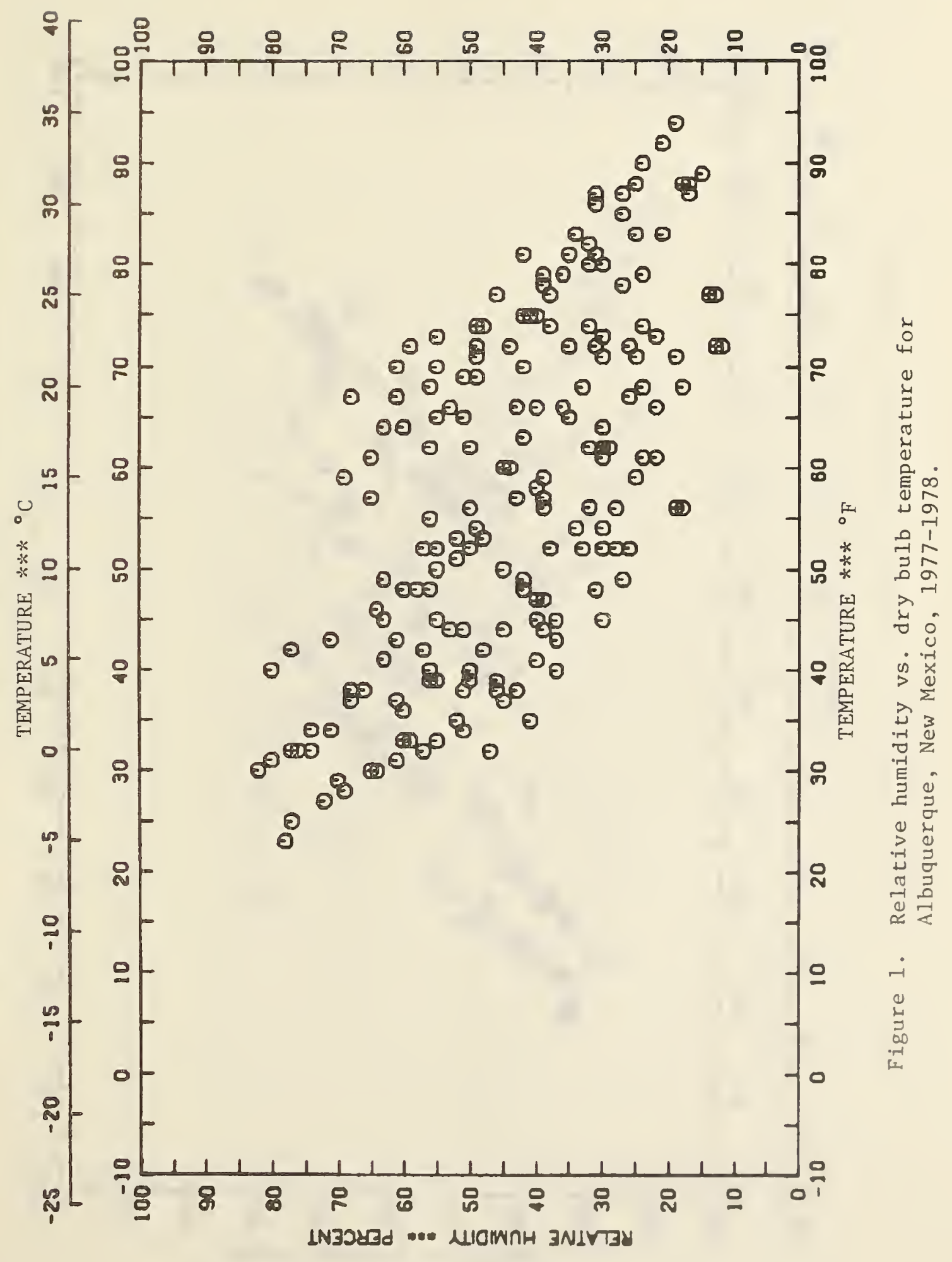




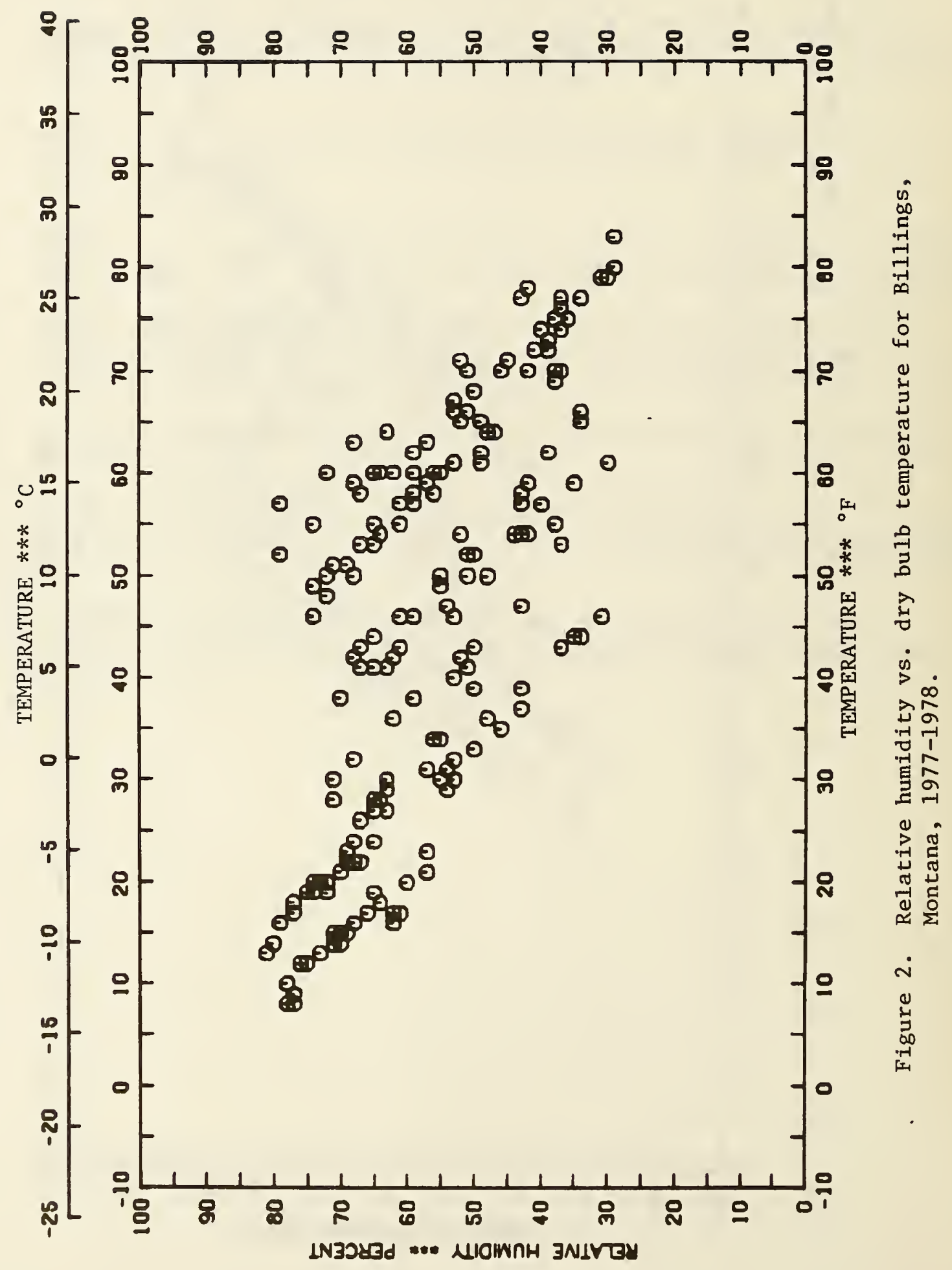




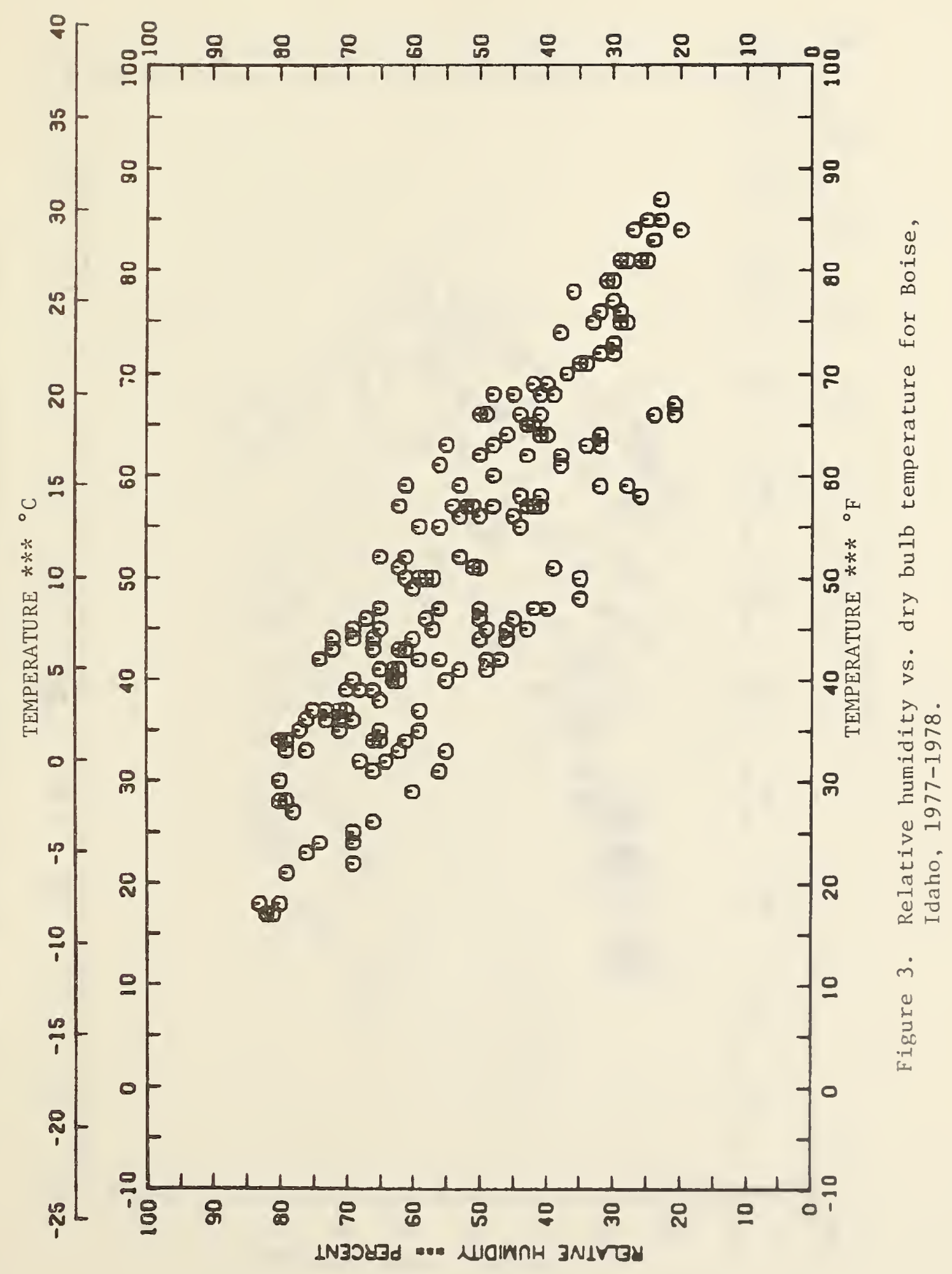




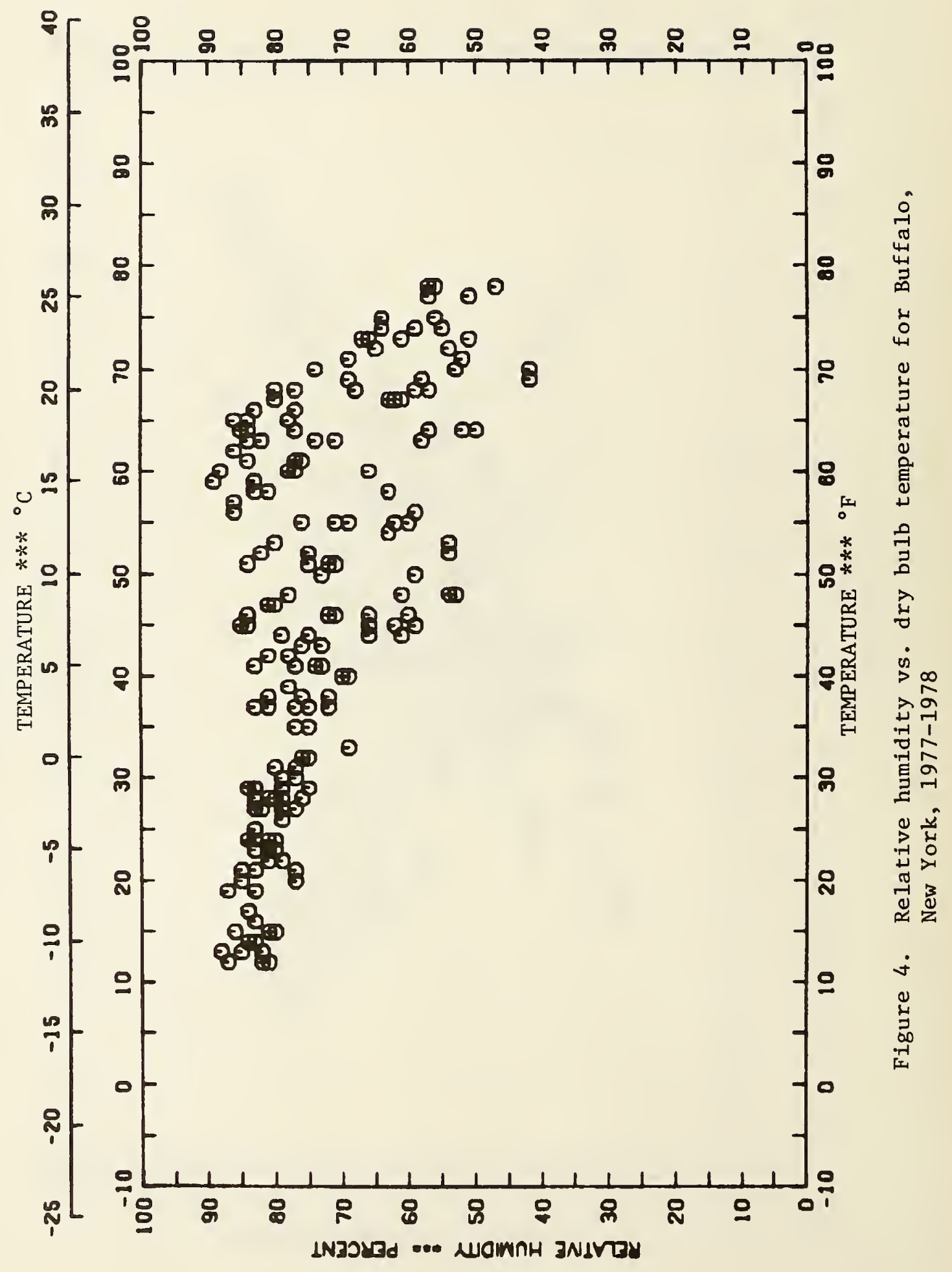




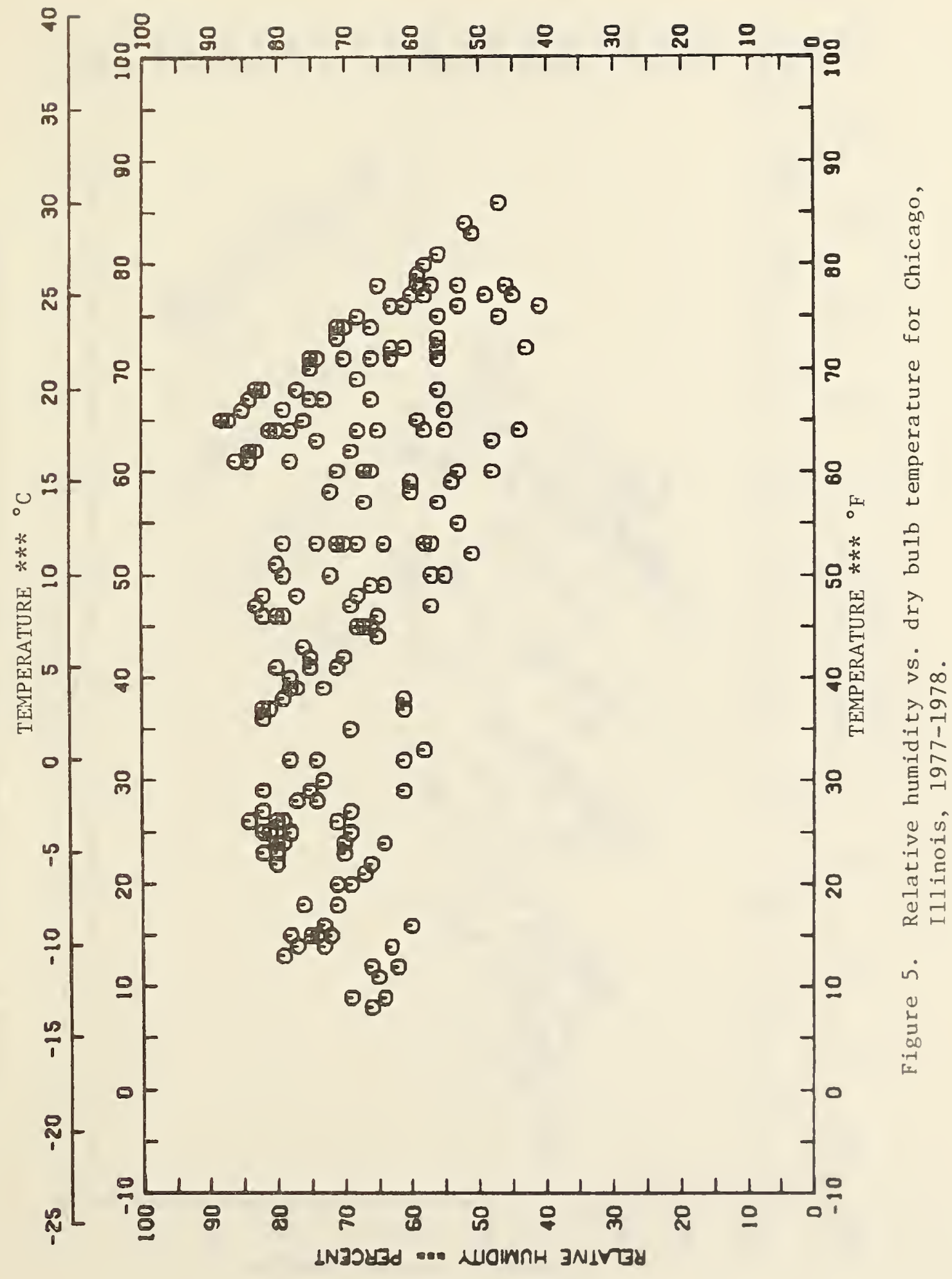




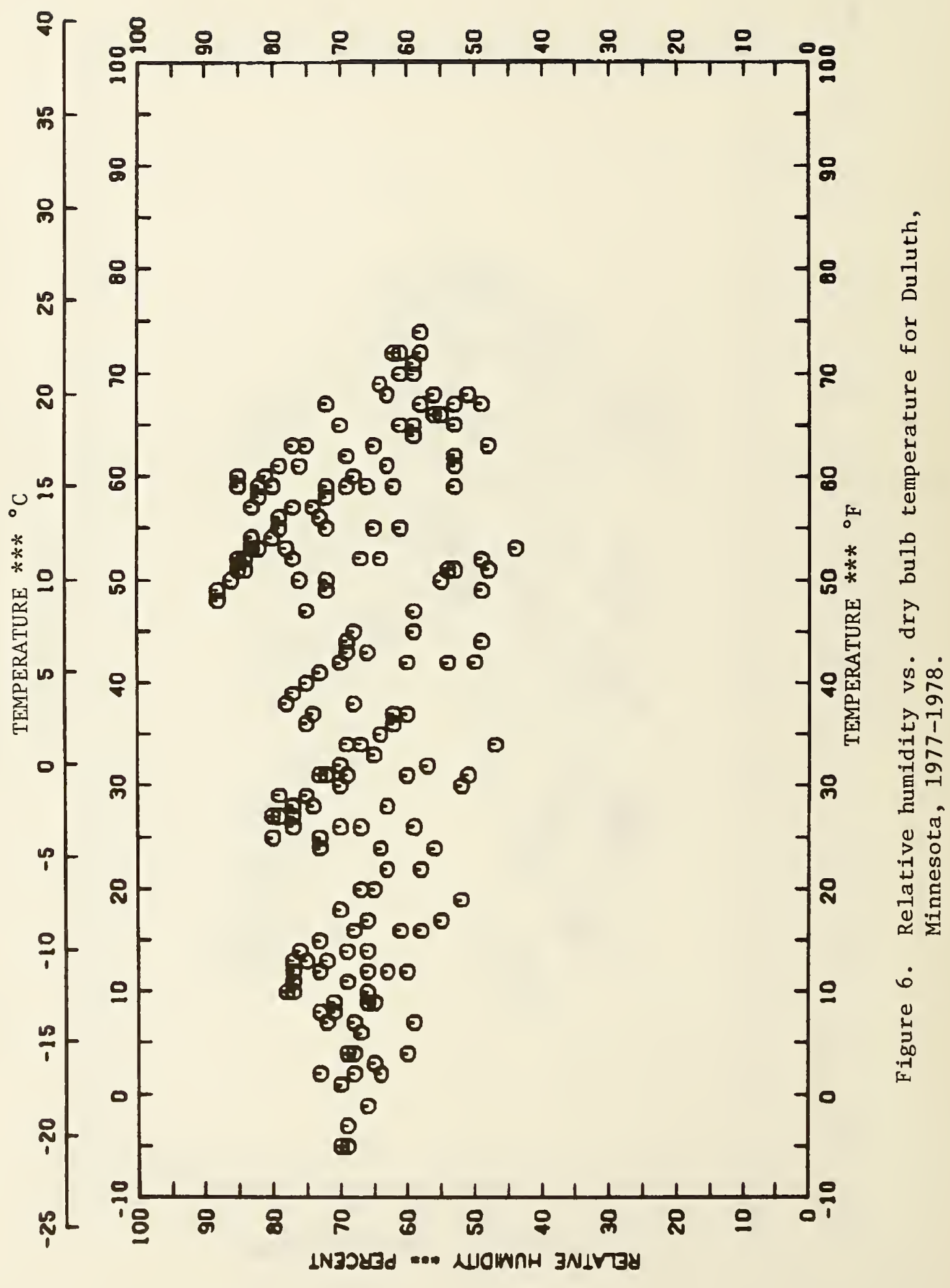




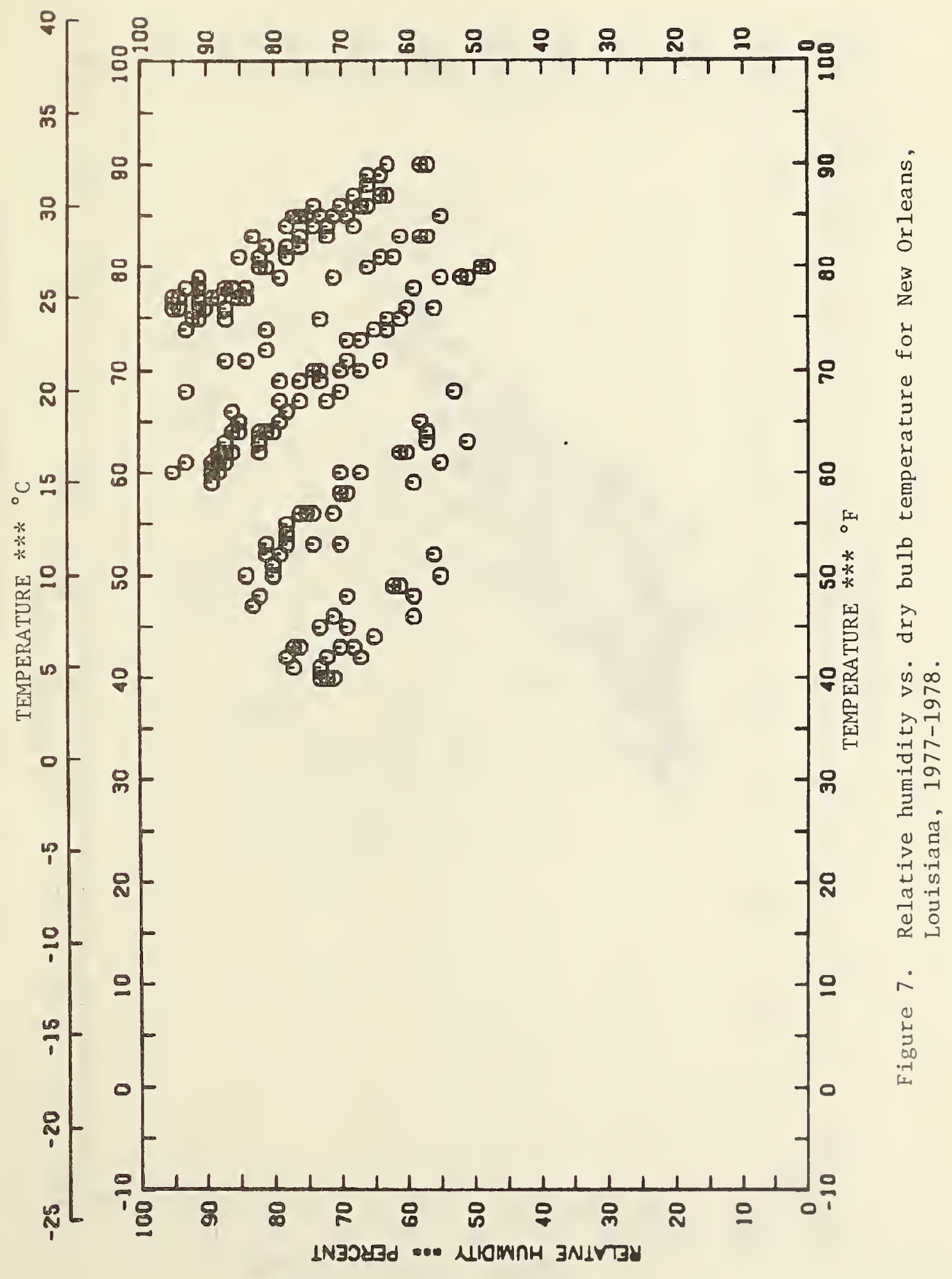




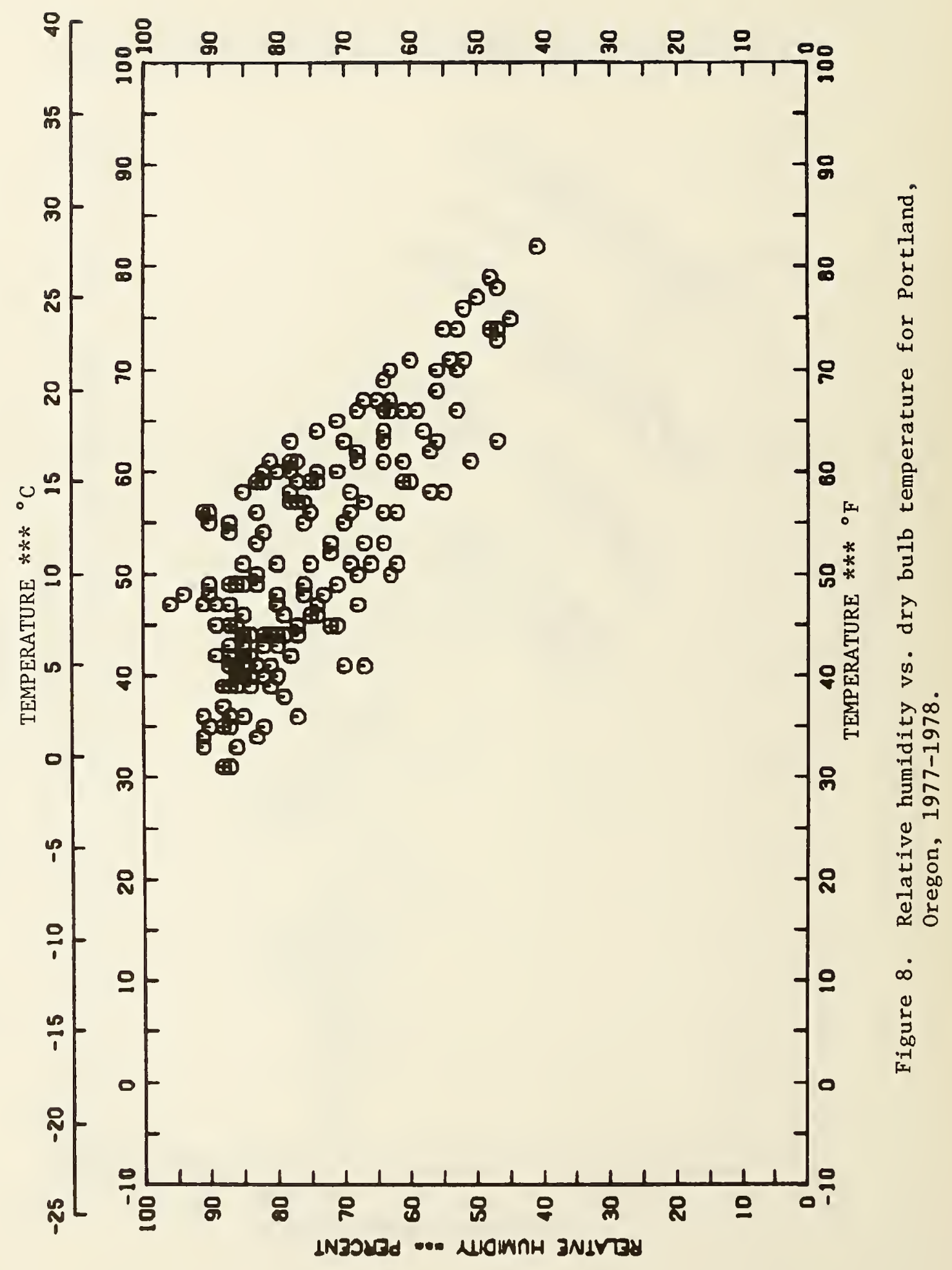




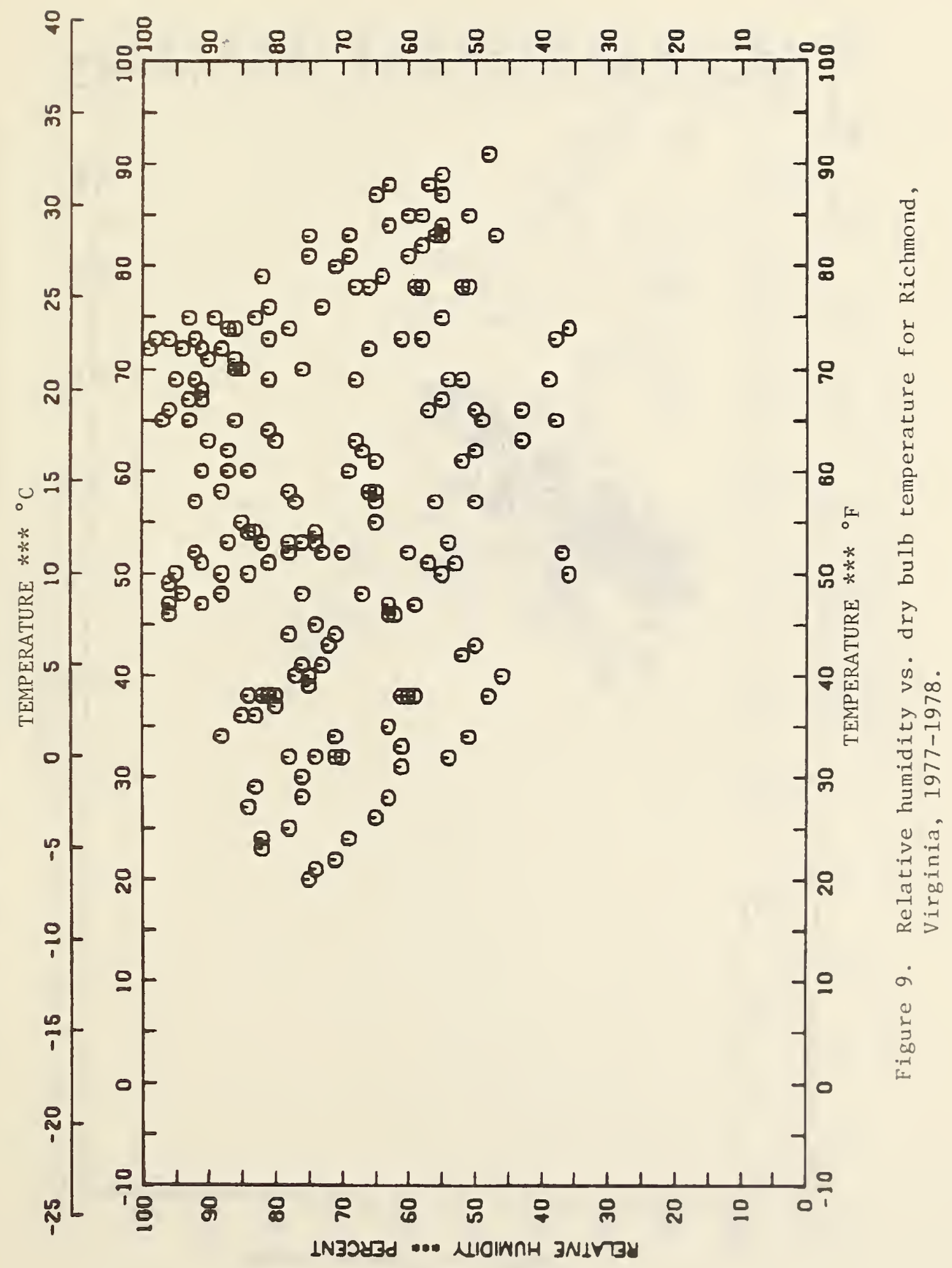




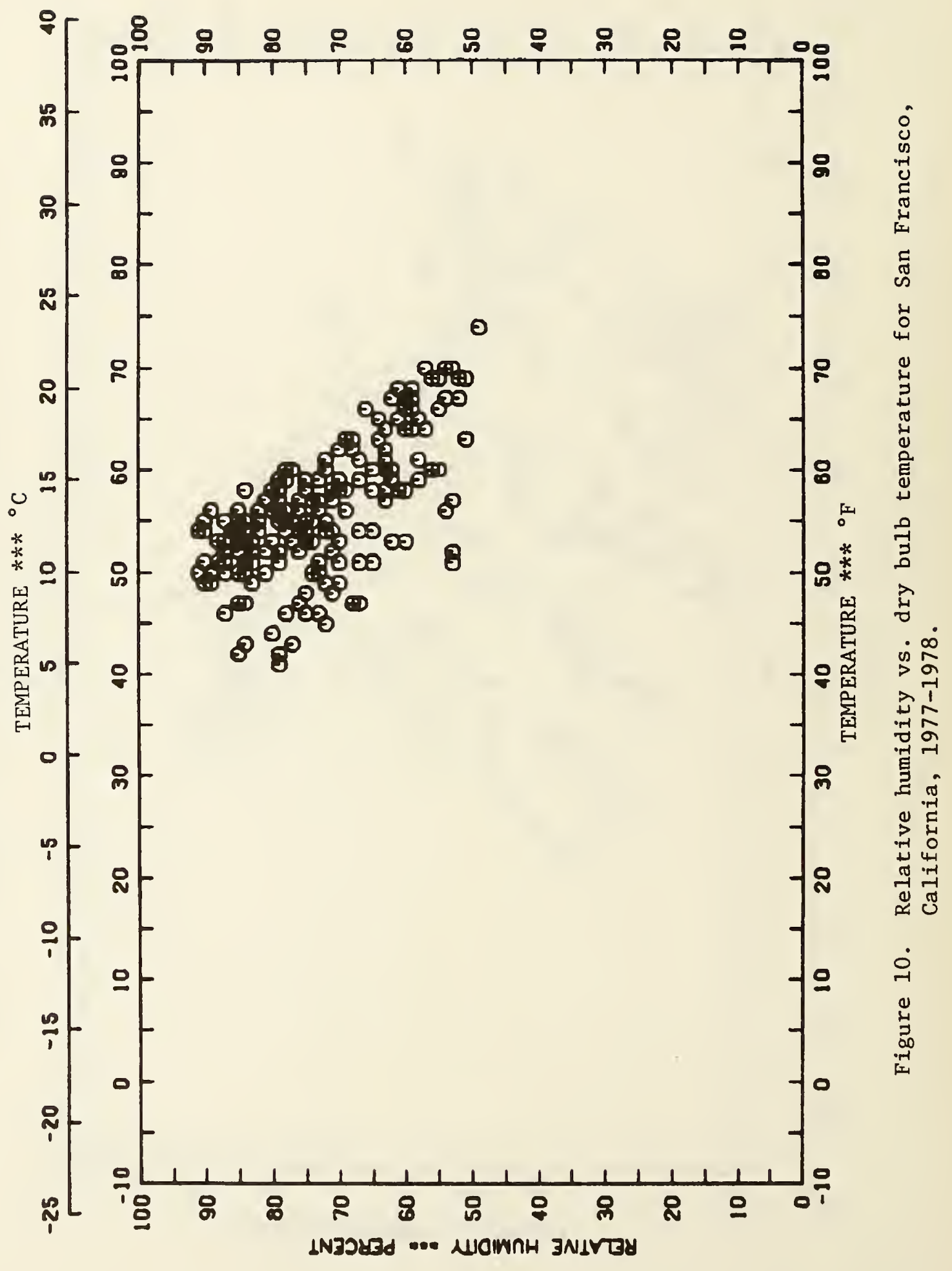




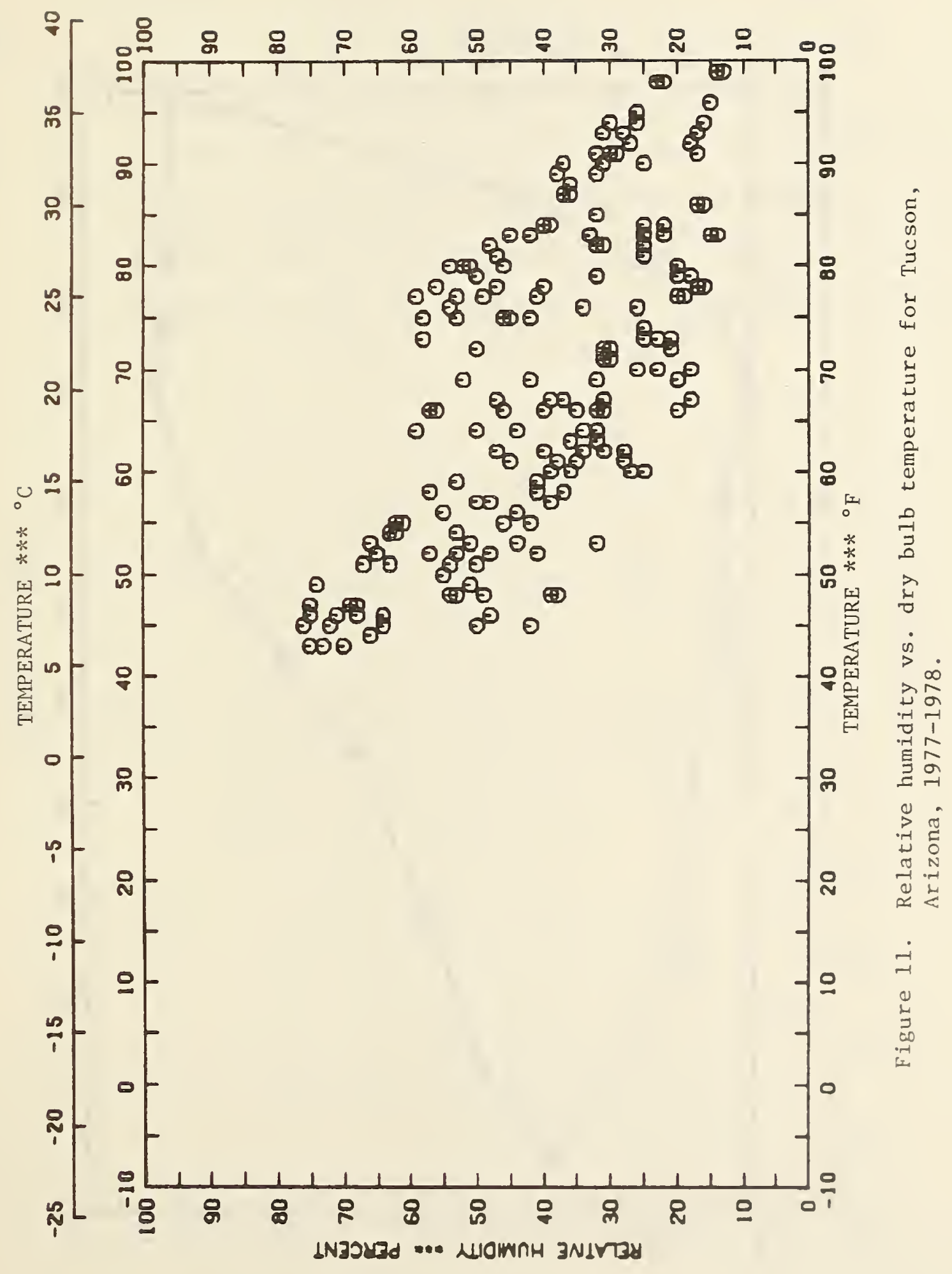




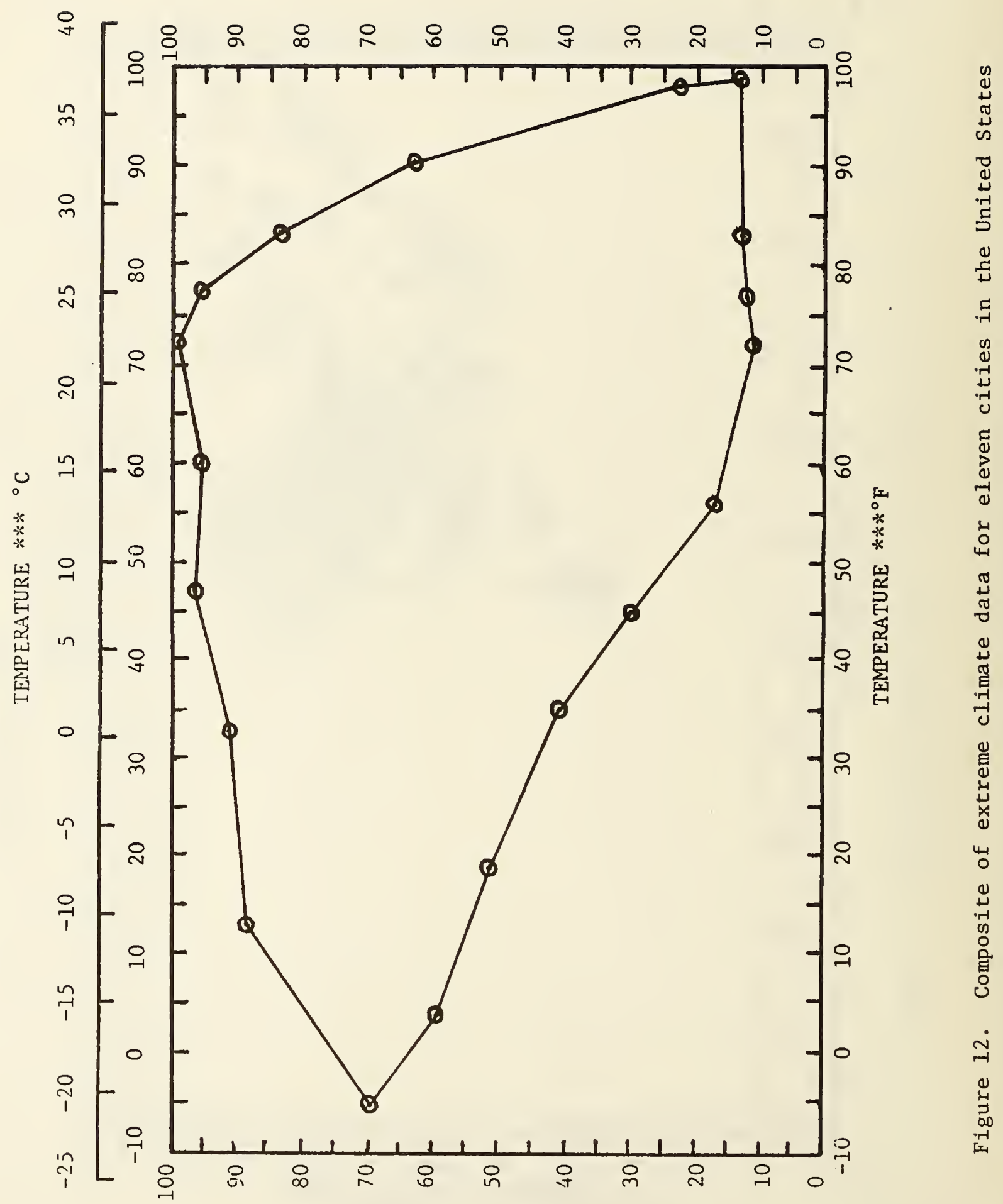

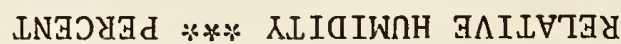


Table 1. Conditioning Cycle Specified in ASTM C 739-77

\section{Cycle}

\section{Condition}

1. $24 \mathrm{hrs}$. C $180 \pm 3^{\circ} \mathrm{F}\left(82.2 \pm 1.7^{\circ} \mathrm{C}\right)$ and $96 \pm 3 \%$ relative humidity

2 . $24 \mathrm{hrs}$. C $80 \pm 3^{\circ} \mathrm{F}\left(26.7 \pm 1.7^{\circ} \mathrm{C}\right)$ and $50 \pm 3 \%$ relative humidity

3. $24 \mathrm{hrs}$. C $180 \pm 3^{\circ} \mathrm{F}\left(82.2 \pm 1.7^{\circ} \mathrm{C}\right)$ and $96 \pm 3 \%$ relative humidity

4. $24 \mathrm{hrs}$. $80 \pm 3^{\circ} \mathrm{F}\left(26.7 \pm 1.7^{\circ} \mathrm{C}\right)$ and $50 \pm 3 \%$ relative humidity 


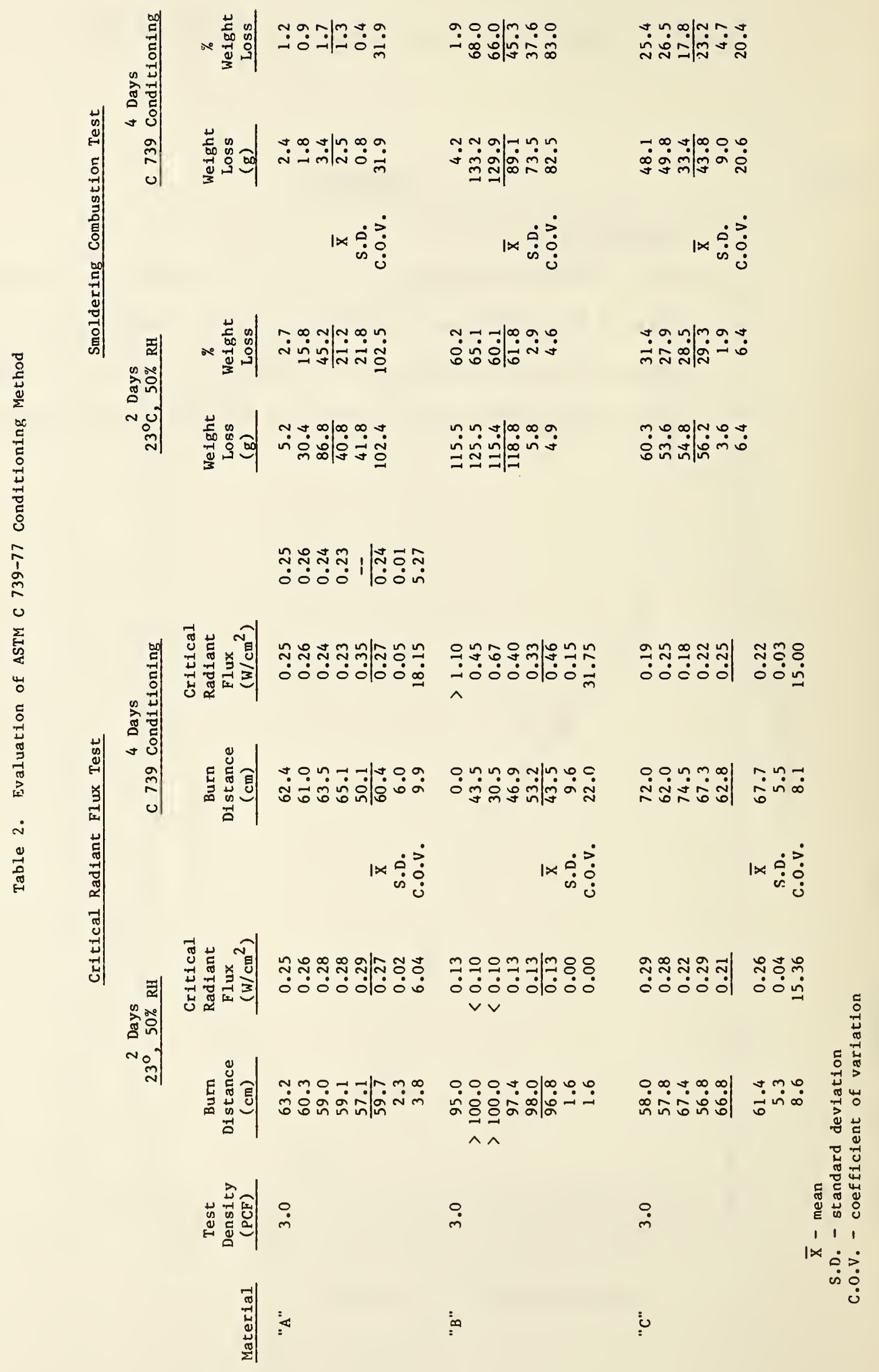


Table 3. Cities Used in the Analysis of Climat1c Conditions

1. Albuquerque, New Mexico

2. B1llings, Montana

3. Bolse, Idaho

4. Buffalo, New York

5. Chicago, Illinois

6. Duluth, Minnesota

7. New Orleans, Loulsiana

8. Portland, Oregon

9. Richmond, Virginia

10. San Francisco, California

11. Tucson, Arizona 
Table 4. Environmental Cycles Used to Condition Specimens

$$
\begin{aligned}
& \text { Baseline - } 4 \text { days } 23^{\circ} \mathrm{C} \text { and } 50 \% \text { relative humidity } \\
& \text { Cycle A - } 4 \text { days } C 60^{\circ} \mathrm{C} \text { and } 10 \% \text { relative humidity, then } \\
& 4 \text { days e } 23^{\circ} \mathrm{C} \text { and } 50 \% \text { relative humidity } \\
& \text { Cycle } \mathrm{B}-4 \text { days } @ 35^{\circ} \mathrm{C} \text { and } 95 \% \text { relative humidity, then } \\
& 4 \text { days } 23^{\circ} \mathrm{C} \text { and } 50 \% \text { relative humidity }
\end{aligned}
$$


Table 5. Composition of Cellulosic Insulation Materials

Specimen

1

2

3

4

5

6
Fire Retardant Chemical Additives

one part borax ( $5 \mathrm{~mol}$ ), two parts boric acid; total chemical content, 25 percent

two parts borax, one part boric acid; total chemical content, 25 percent

one part borax, one part boric acid, one part aluminum trihydrate; total chemical content, 25 percent

one part borax, four parts ammonium sulfate; total chemical content, 25 percent

two parts borax, two parts boric acid, one part aluminum sulfate (alum); total chemical content, 25 percent

two parts reacted boric acid/sodium sulfate (e.g., Boron-10), one part boric acid; total chemical content, 25 percent 
Table 6. Blown and Settled Densities for Cellulosic Thermal Insulation Samples

\begin{tabular}{|c|c|c|c|c|}
\hline Material & $\begin{array}{c}\text { Blown } \\
\text { Density } \\
\left(\mathrm{kg} / \mathrm{m}^{3}\right) \\
\end{array}$ & $\begin{array}{c}\text { Average } \\
\text { Blown } \\
\text { Dens1ty } \\
\left(\mathrm{kg} / \mathrm{m}^{3}\right) \\
\end{array}$ & $\begin{array}{l}\text { Settled } \\
\text { Density } \\
\left(\mathrm{kg} / \mathrm{m}^{3}\right) \\
\end{array}$ & $\begin{array}{l}\text { Average } \\
\text { Settled } \\
\text { Densitty } \\
\left(\mathrm{kg} / \mathrm{m}^{3}\right)\end{array}$ \\
\hline 1 & $\begin{array}{l}32.9 \\
33.0 \\
34.2 \\
34.9\end{array}$ & 33.7 & $\begin{array}{l}49.3 \\
50.9 \\
51.3 \\
50.1\end{array}$ & 50.4 \\
\hline 2 & $\begin{array}{l}35.4 \\
37.5 \\
34.4 \\
35.3\end{array}$ & 35.7 & $\begin{array}{l}53.3 \\
52.0 \\
51.1 \\
51.4\end{array}$ & 51.9 \\
\hline 3 & $\begin{array}{l}34.1 \\
32.2 \\
31.8 \\
35.6\end{array}$ & 33.4 & $\begin{array}{l}50.1 \\
50.6 \\
48.7 \\
50.7\end{array}$ & 50.0 \\
\hline 4 & $\begin{array}{l}35.3 \\
32.6 \\
33.7 \\
33.1\end{array}$ & 33.6 & $\begin{array}{l}52.8 \\
51.3 \\
50.7 \\
48.4\end{array}$ & 50.8 \\
\hline 5 & $\begin{array}{l}30.1 \\
29.3 \\
31.8 \\
31.4\end{array}$ & 30.6 & $\begin{array}{l}47.0 \\
45.0 \\
45.7 \\
48.6\end{array}$ & 46.6 \\
\hline 6 & $\begin{array}{l}35.2 \\
32.6 \\
34.2 \\
34.0\end{array}$ & 34.0 & $\begin{array}{l}50.4 \\
51.6 \\
46.6 \\
49.5\end{array}$ & 49.5 \\
\hline
\end{tabular}




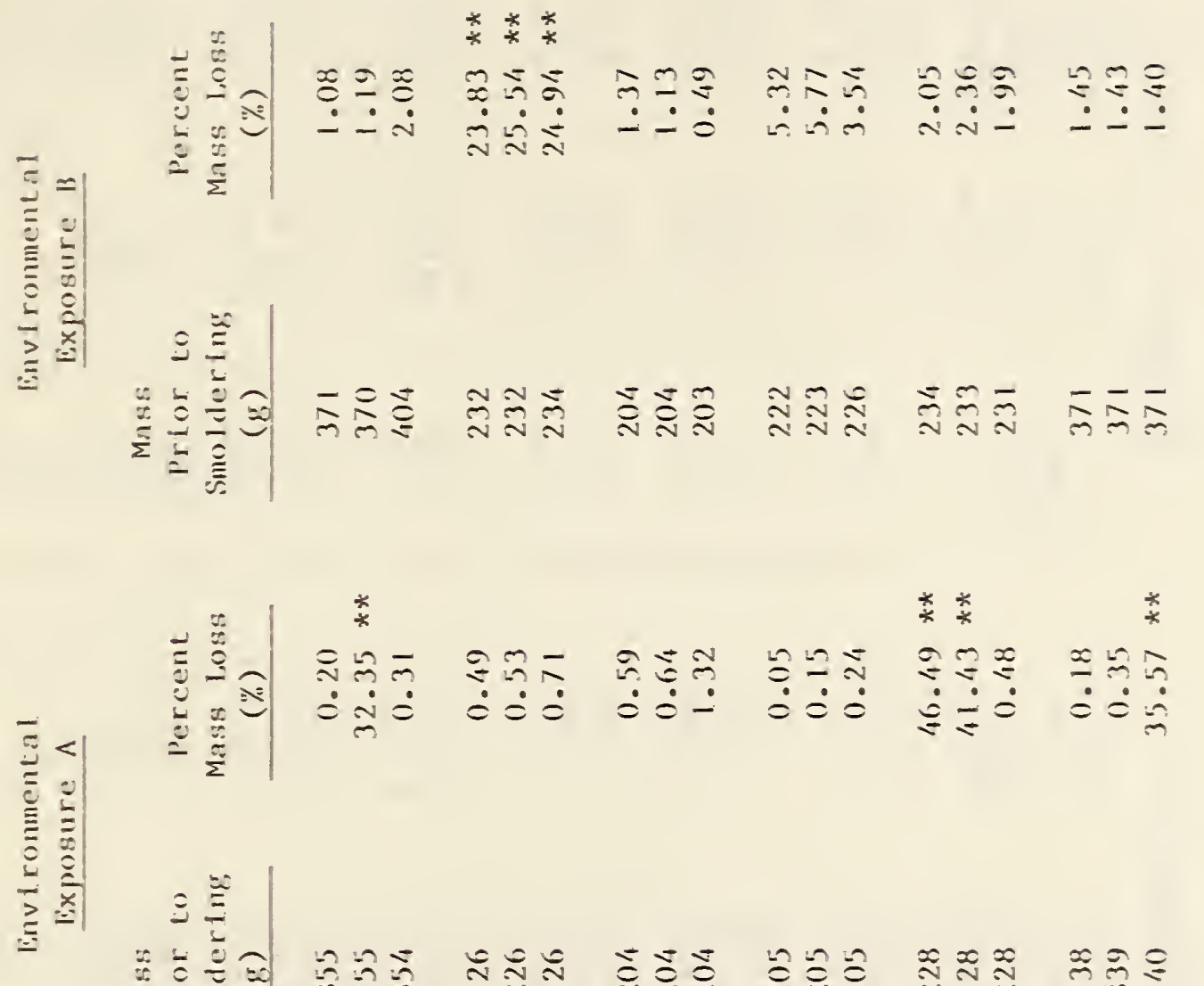

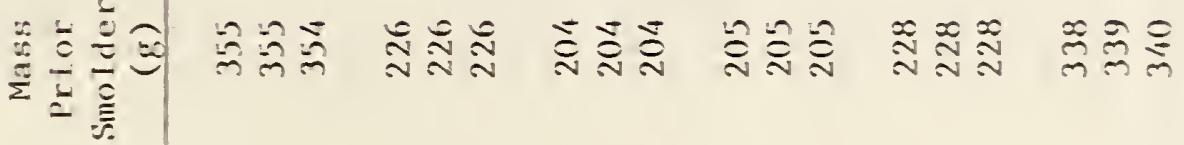

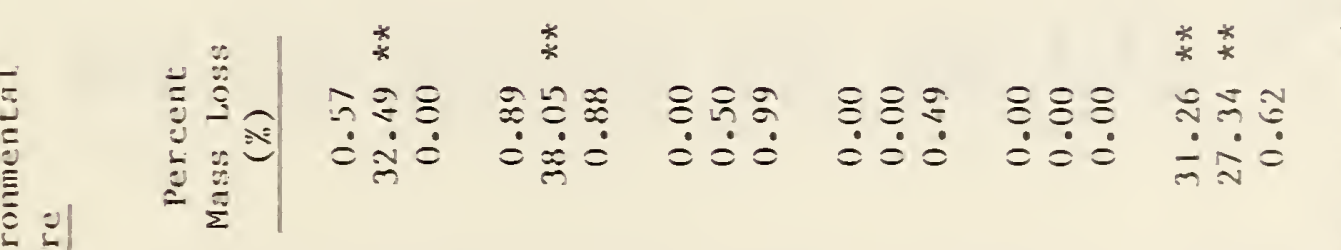

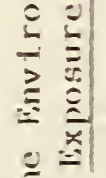

垔

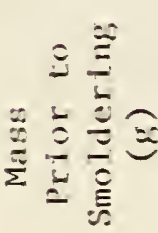

$\hat{n}=\frac{\pi}{n}$

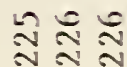

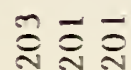

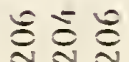

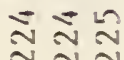

n

$\stackrel{0}{\underline{x}}$

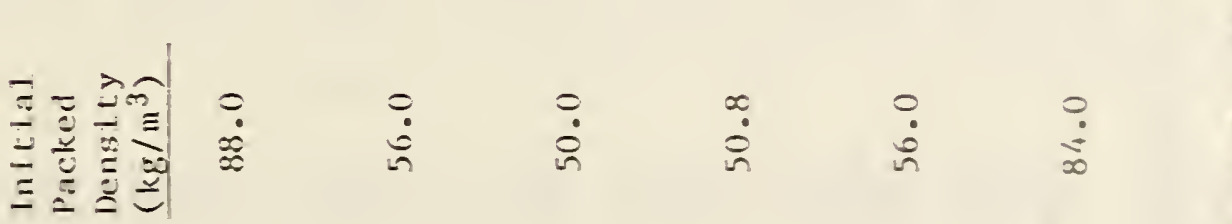




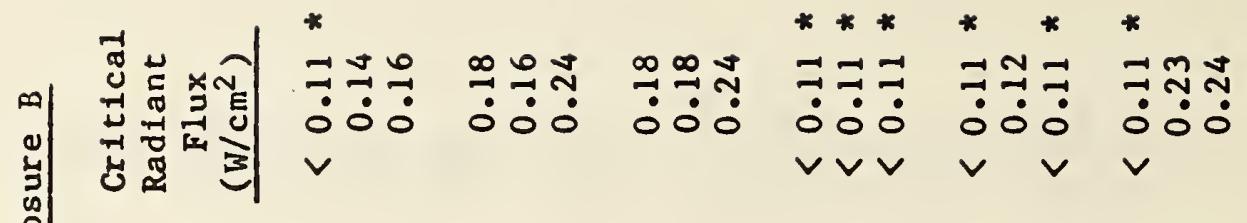

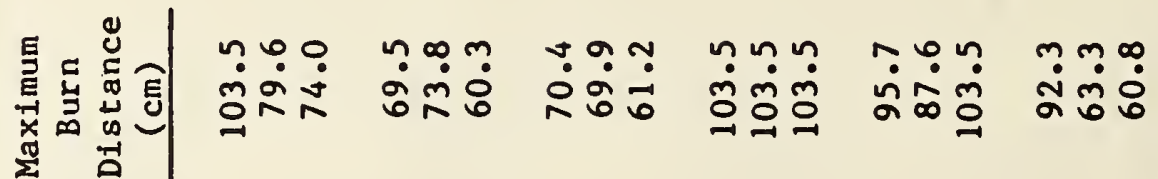

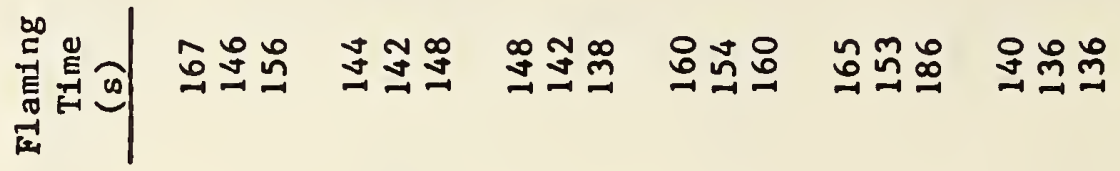

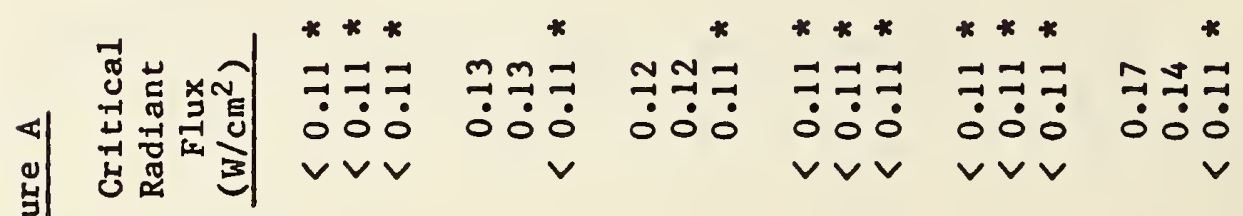

至

ำ่

บำ:

กินก ?

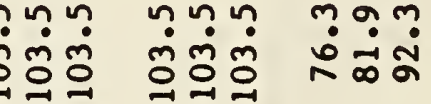

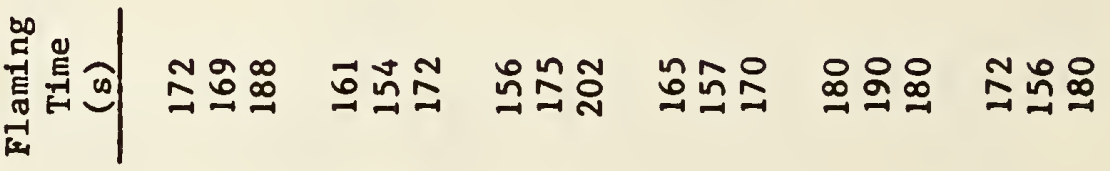

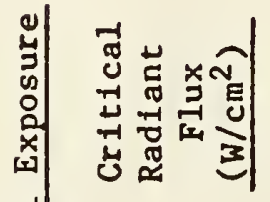

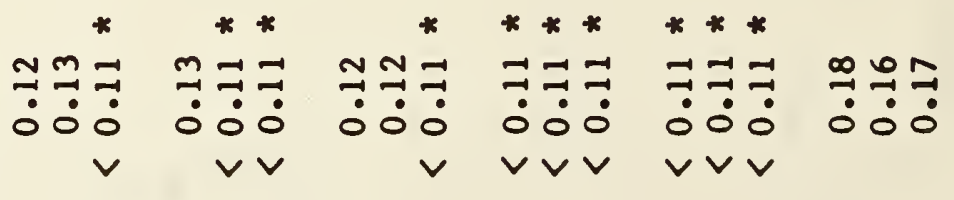

章结

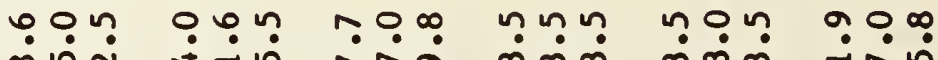

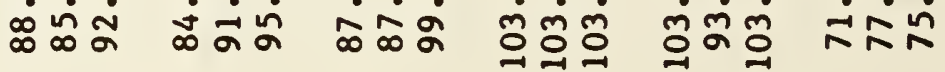

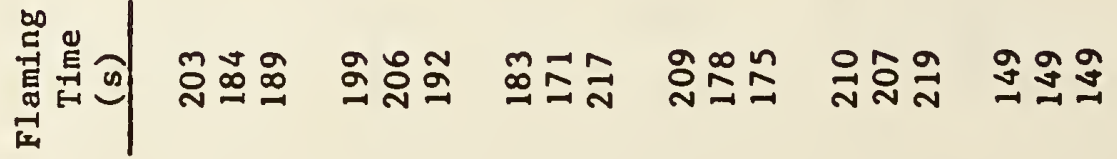

$n$

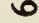


4. TITLE AND SUBTITLE

Environmental Cycling of Cellulosic Thermal Insulation and

Its Influence on Fire Performance

\section{5. $A \cup T H O R(S)$}

\section{J . Randa11 Lawson}

6. PERFORMING ORGANIZATION (If joint or other than NBS, see instructions)

NATIONAL BUREAU OF STANDARDS

DEPARTMENT OF COMMERCE

WASHINGTON, D.C. 20234

\section{SF ONSORING ORGANIZATION NAME AND COMPLETE ADDRESS (Street, City, Stote, ZIP)}

Department of Energy

Washington, D.C.

10. SUPPLEMENTARY NOTES

[] Document describes a computer program; SF-185, FIPS Software Summary, is attached.

11. ABSTRACT (A 200-word or less factual summary of most significant information. If document includes a significant bibliography or literature survey, mention it here)

A study was conducted on climatological data for eleven cities located throughout the United States. Findings from this environmental study were used to develop conditioning cycles for a research project on the influence of environments on the fire performance of loose-fill cellulosic thermal insulation. Six cellulosic insulation materials containing 25 percent by weight of fire retardant chemical add-on of different compositions were specially manufactured for this study. These materials were tested to establish a baseline.

After the materials were exposed to the various environmental cycles, they were tested for fire performance. Results from these tests show that environmental exposure can have a significant effect on the fire performance of cellulosic insulation materials and indicates that long term fire protection provided by fire retardant compounds may be limited.

12. KEY WORDS (Six to twelve entries; alphabetical order; copitalize only proper names; and separate key words ty semicalons) Climate; cellulose; environments; fire performance; fire retardants; thermal insulation.

13. AVAILABILITY

Unlimited

For Official Distribution. Do Not Release to NTIS

[.] Order From Superintendent of Documents, U.S. Government Printing Office, Washington, D.C. 20402.

14. NO. OF

PRINTED PAGES

46

15. Prise

[X] Order From National Technical Information Service (NTIS), Springfield, VA. 2216I 


